\title{
Ornamen Masjid Jami Kajen serta Kontribusinya dalam Penguatan Pendidikan Karakter di Madrasah Ibtidaiyah
}

\author{
M. Sofyan Alnashr \\ Institut Pesantren Mathali'ul Falah Pati \\ email: sofyan@ipmafa.ac.id
}

Jl. Raya Pati - Tayu Kedung, Purwerejo, Margoyoso, Pati, Jawa Timur

Received: Nov 14, 2019

Revised: Feb 22, 2020

Accepted: April 8, 2020

\begin{abstract}
This study aimed to explain the meaning of ornaments contained in the Jami Kajen Mosque and its contribution in strengthening character education of children in Madrasah Ibtidaiyah. This research was a qualitative descriptive study with a philosophical interpretative approach to find the meaning behind the mosque's ornaments then relate it to teaching material of PAI MI and find its contribution to the strengthening of the character education of MI students. The results showed, first, the ornaments contained in the Jami Kajen Mosque contained philosophical meaning in containing Islamic teachings and local wisdom conveyed by Shaykh Mutamakkin through art. Ornaments with symbolic meanings were found in the Jami Kajen Mosque, namely the sculpture of Kuntul Nucuk Bulan, Naga Aji Saka, Gajah-Trisula-Taman, Corresponding Board, and Mosque Sky Calligraphy. The teachings conveyed came from Islamic teachings sourced from the Qur'an and Hadith as well as teachings from Javanese tradition and culture. Second, ornaments with the meaning of the content of Islamic teachings and local culture in the Jami Kajen Mosque make a major contribution to the strengthening of the character of MI students through learning based on local wisdom of the Jami Kajen Mosque as a source of learning and learning media. Active learning and contextual learning to strengthen the character of MI students can be done by making the ornaments of the Jami Kajen Mosque as the basis of learning of PAI MI.
\end{abstract}

Keywords: mosque ornament, character education, learning, MI

\begin{abstract}
Abstrak
Penelitian ini bertujuan menjelaskan makna ornamen yang terdapat dalam Masjid Jami Kajen dan kontribusinya dalam penguatan pendidikan karakter di Madrasah Ibtidaiyah. Penelitian ini merupakan penelitian diskriptif kualitatif dengan pendekatan interpretatif filisofis untuk menemukan makna di balik ornamen masjid kemudian mengaitkannya dengan materi ajar PAI MI dan menemukan kontribusinya bagi penguatan karakter anak didik MI. Hasil penelitian menunjukkan, pertama, ornamen yang terdapat dalam Masjid Jami Kajen memiliki kandungan makna filosofis yang dalam berisi ajaran Islam dan kearifan lokal yang disampaikan oleh Syaikh Mutamakkin melalui karya seni. Ornamen dengan makna simbolik yang terdapat dalam Masjid Jami Kajen yaitu pahatan Kuntul Nucuk Bulan, Naga Aji Saka, Gajah-Trisula-Taman, Papan Bersurat, dan Kaligrafi Langit Masjid. Ajaran yang disampaikan berasal dari ajaran Islam yang bersumber dari Al-Qur'an dan Hadis serta
\end{abstract}


ajaran dari tradisi dan kebudayaan Jawa. Kedua, ornamen dengan makna kandungan ajaran Islam dan budaya lokal dalam Masjid Jami Kajen memberikan kontribusi besar bagi penguatan pendidikan karakter anak didik MI melalui pembelajaran yang berbasis pada kearifan lokal Masjid Jami Kajen sebagai sumber belajar maupun media pembelajaran. Pembelajaran aktif dan pembelajaran kontektual untuk menguatkan karakter anak didik MI dapat dilakukan dengan menjadikan ornamen Masjid Jami Kajen sebagai basis pembelajaran PAI MI.

Kata Kunci: ornamen masjid, pendidikann karakter, pembelajaran, MI

\section{Pendahuluan}

Di nusantara pada masa awal perkembangan Islam, masjid menjadi pusat peradaban sekaligus lembaga yang tidak dapat dipisahkan dari kehidupan masyarakat. Islam berkembang seiring dengan meningkatnya kesadaran masyarakat Islam memakmurkan masjid dengan berbagai aktivitas sosial dan budaya. Pada tahap ini, masjid berkembang sesuai dengan corak dan karakteristik masyarakatnya, ajaran Islam menyatu dalam tradisi dan budaya lokal sepanjang tidak melanggar syariat Islam. Kalaupun melanggar syariat, para ulama penyebar Islam di nusantara menggantinya dengan sesuatu yang sesuai ajaran Islam. Menghormati orang yang meninggal dengan berkumpul di rumah duka yang awalnya disuguhi minuman keras diganti dengan berkumpul membaca kalimat tauhid dan mendoakan mayat sehingga lahirlah yang disebut dengan tahlilan. Terdapat juga tradisi kenduri dengan ingkungnya, sesajen, sedekah bumi, serta tradisi lain yang tidak serta merta diharamkan tetapi diakomodir dan disesuaikan dengan ajaran agama Islam.

Syaikh Ahmad Mutamakkin merupakan salah satu ulama penyebar agama Islam di pesisir utara Jawa Tengah yang mengajarkan Islam namun tetap menjaga tradisi dan budaya lokal. Syaikh Mutamakkin, menurut Gus Dur, mengawali tradisi pengembangan ajaran agama Islam yang disebut dengan pendekatan kultural. ${ }^{1}$ Contoh nyatanya adalah didirikannya Masjid Jami Kajen dengan bentuk yang khas budaya jawa serta ornamen-ornamen yang

${ }^{1}$ Ahmad Ubaidillah dan Yuliatin Tajuddin, Suluk Kiai Cebolek (Dalam Konflik Keberagamaan dan Kearifan Lokal), (Jakarta: Prenada, 2014) mirip ornamen keraton di nusantara. Mimbar masjid ini memiliki ukiran dua kepala naga yang menurut Bizawie ${ }^{2}$ melambangkan Naga Aji Saka, legenda penyebar Islam di tanah Jawa.

Masjid Jami Kajen berdiri pada tahun $1107 \mathrm{H}^{3}$ atau tahun $1695 \mathrm{M}$ berdasarkan candrasengkala di mihrab masjid berbunyi sang pandita (7) kuwi ngawang (10) bawana (1) didirikan oleh Syaikh Mutamakkin dan Haji Syamsudin. Masjid ini sangat menarik karena mempertahankan bentuk bangunan asli meskipun telah mengalami beberapa kali renovasi. Bahkan kayu yang digunakan sebagai dinding, mimbar, atau ornamen lain masih tetap menggunakan bangunan aslinya. Kecuali beberapa bahan seperti genteng yang diganti dengan genteng tanah liat karena lebih awet dan kokoh. Sementara dinding kayu dan tegelnya masih asli sejak pertama kali dibangun yang berati sudah berusia ratusan tahun.

Melalui masjid ini, Syaikh Mutamakkin mengajar dan menyebarkan Islam di daerah yang saat ini secara administratif masuk wilayah Kabupaten Pati, tepatnya di Desa Kajen Kecamatan Margoyoso. Syaikh Mutamakkin menjadikan Masjid Jami Kajen sebagai pusat peradaban dan aktivitas masyarakat mulai dari beribadah, belajar agama, peningkatan ekonomi, kegiatan sosial budaya, dan banyak lagi lainnya. Bahkan sampai saat ini, tradisi

${ }^{2}$ Zainul Milal Bizawie, Syaikh Mutamakkin Perlawanan Kultural Agama Rakyat. (Tangerang: Compas Pustaka, 2014)

${ }^{3}$ Ahmad Syafii Mufid, Tangklukan, Abangan, dan Tarekat: Kebangkitan Agama di Jawa, (Jakarta: Yayasan Obor Indonesia, 2006) 
suronan, sedekah bumi, atau santunan anak yatim diselenggarakan di masjid.

Masjid Jami Kajen sebagaimana masjid kuno lainnya menampilkan karya seni dan ornamen dengan nilai estetika yang tinggi. Masjid Jami Kajen dibangun dengan kontruksi gaya panggung, tidak memiliki kubah namun berupa atap tumpang seperti di Masjid Agung Demak. Atap tumpang tiga tersebut dapat dimaknai sebagai ajaran tentang Iman, Islam, dan Ihsan. Masjid menjadi representasi perpaduan budaya Islam dan Jawa.

Lantas, bagaimana kontribusi Masjid Jami Kajen dalam perkembangan pendidikan Islam sekarang di mana kegiatan pendidikan Islam lebih banyak dilakukan melalui pembelajaran di dalam ruang kelas dalam lingkup lembaga pendidikan formal? Pertanyaan ini yang menjadi dasar penelitian lebih lanjut terkait fungsi masjid dengan fokus pada pemaknaan ornamen Masjid Jami Kajen serta kontribusinya dalam penguatan karakter mandiri di Madrasah Ibtidaiyah (MI).

Belum banyak penelitian tentang Masjid Jami Kajen terutama kontribusinya dalam pembelajaran PAI di Madrasah Ibtidaiyah. Akan tetapi beberapa penelitian dapat dijadikan sebagai kajian pustaka sekaligus menunjukkan distingsi penelitian ini dengan karya penelitian sebelumnya. Novita ${ }^{4}$ dalam penelitiannya berjudul Mengenal Masjid Nahdliyin dalam Peranan Masjid Jami Kajen memaparkan bagaimana peranan Masjid Jami Kajen sebagai pusat peradaban di desa Kajen yang tidak hanya berfungsi sebagai tempat shalat saja tetapi juga menjadi pusat kegiatan keagamaan masyarakat seperti mengkaji dan mengaji kitab, santunan fakir miskin dan anak yatim, tradisi suronan, megengan, serta berbagai aktivitas lainnya. Penelitian sekarang berbeda karena mengambil fokus pada makna

${ }^{4}$ Novita Siswayanti, "Mengenal Masjid Nahdliyin dalam Peranan Masjid Jami Kajen", Bimas Islam, VII, No. II (2018), h. 277-300 ornamen Masjid Jami Kajen dan kontribusinya dalam penguatan karakter mandiri di MI.

Kajian tentang perkembangan masjid dapat ditemukan dari penelitian Kurniawan ${ }^{5}$ yang mengkaji masjid dalam lintasan sejarah umat Islam. Menurutnya saat ini banyak ditemui masjid yang hanya berfungsi sebagai tempat shalat, sementara masjid era kejayaan Islam juga berfungsi sebagai pusat perkembangan segala aspek kehidupan masyarakat utamanya ialah pembinaan aqidah dan akhlak jamaah. Sejalan dengan ini ialah penelitian Hidayat ${ }^{6}$ yang mengajak umat Islam untuk menginterpretasikan agama berdasarkan keadaan sosial budaya. Masjid, menurutnya, dalam peradaban baru adalah masjid yang mampu membentuk spiritualitas manusia -secara individu- untuk mendapatkan nilainilai kehidupan yang kompleks -sosial-.

Sementara kajian tentang ornamen masjid dilakukan oleh Supriyadi ${ }^{7}$ yang meneliti ornamen pada Masjid Agung Demak dan Masjid Menara Kudus. Menurutnya ornamen pada kedua masjid tersebut memiliki corak yang berbeda sesuai dengan karkateristik masyarakat dan ulamanya. Sementara Ilhaq ${ }^{8}$ meneliti ornamen pada Mesjid Agung Palembang yang merupakan perpaduan antara bidang geometris, kaligrafi Arab, dan motif tumbuhan dengan seni ukir Palembang yang khas menghasilkan keindahan visual dengan mengikuti perkembangan zaman.

Melihat warisan budaya dalam ornamen Masjid Jami Kajen secara filosofis kemudian menganalisnya secara kontekstual berkenaan dengan kontribusinya dalam pendidikan Islam

${ }^{5}$ Syamsul Kurniawan, "Masjid dalam Lintasan Sejarah Umat Islam", Jurnal Katulistiwa - Journal of Islamic Studies, 4 No. 2, (2014), h. 169-184

${ }^{6}$ Arif Hidayat, "Masjid dalam Menyikapi Peradaban Baru", Ibda': Jurnal Kebudayaan Islam, 12 (1), (2014), h. 13-26

${ }^{7}$ Bambang Supriyadi, "Kajian Ornamen Pada Mesjid Bersejarah Kawasan Pantura Jawa Tengah", Enclosure, 7 (2), (2008), h. 106-121

${ }^{8}$ Muhsin Ilhaq, "Bentuk dan Penempatan Ornamen pada Mesjid Agung Palembang", Jurnal Ekspresi Seni, 18(2), (2016), h. 180-194 
menjadi topik yang menarik dikaji lebih dalam. Maka penelitian ini mencoba menjelaskan bagaimana kontribusi akulturasi budaya dalam ornamen Masjid Jami Kajen dalam pembelajaran PAI di lembaga pendidikan Islam tingkat dasar. Apalagi masa pendidikan dasar ialah masa pembentukan karakter bagi anak didik, tentu pembelajaran yang berbasis pada kearifan lokal yang dilihat dalam konteks kekinian akan sangat membantu penguatan karakter dalam diri anak didik MI.

\section{Metode Penelitian}

Penelitian ini merupakan penelitian kualitatif di mana mencoba mendiskriptifkan objek penelitian melalui kata-kata sehingga mudah dipahami. Penelitian menggunakan pendekatan filosofis dengan menjadikan ornamen Masjid Jami Kajen sebagai objek penelitian. Untuk mengetahui makna filosofis dari ornamennya, penelitian ini menggunakan teknik analisis interpretasi filosofis. Pengumpulan data dilakukan dengan menggunakan observasi, dokumentasi, dan wawancara yang kemudian dianalisis dengan metode triangulasi untuk mendapatkan data yang valid.

Analisis filosofis terhadap ornamen Masjid Jami Kajen kemudian dilanjutkan dengan melakukan interpretasi dalam bidang pendidikan dasar Islam sesuai konteks kekinian. Makna simbol dari ornamen masjid dikaji lebih dalam untuk menemukan kontribusinya bagi pembelajaran PAI di Madrasah Ibtidaiyah. Hal ini dilakukan dengan mengaitkan makna simbol dengan materi ajar dalam mata pelajaran PAI di Madrasah, baik Aqidah Akhlak, Fiqh, Al-Qur'an Hadis, maupun Sejarah Kebudayaan Islam (SKI).

\section{Hasil dan Pembahasan}

\section{Makna Ornamen Masjid Jami Kajen}

Masjid Jami Kajen dengan bentuk bangunannya yang khas dihiasi berbagai ornamen yang indah tidak hanya menjadi

tempat beribadah, namun juga memiliki nilai edukatif dari setiap ornamennya. Syekh Ahmad Mutamakkin dalam membangun masjid sangat memperhatikan estetika sekaligus menjadikannya sebagai media dakwah kepada masyarakat. Maka tidak mengherankan apabila Masjid Jami Kajen memiliki nilai seni yang tinggi sekaligus mengandung makna yang dalam dari setiap ornamennya.

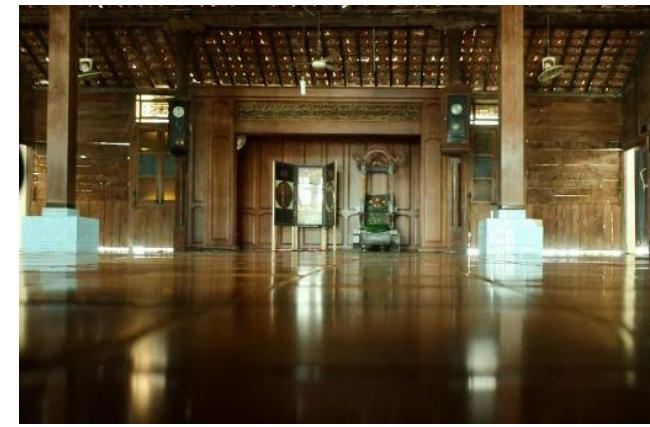

Gambar 1

\section{Ruangan dalam Masjid Jami Kajen}

Ornamen Masjid Jami Kajen di antaranya ialah mimbar yang penuh dengan seni ukir seperti Kuntul Nucuk Bulan, Naga Aji Saka, Gajah membawa trisula di taman, papan bersurat, kaligrafi di langit-langit, serta berbagai motif tanaman. Pendekatan Kultural dari pendiri masjid ini -Syaikh Mutamakkinsangat jelas terlihat dari ornamen yang ada di masjid tersebut. Ornamen hewan dan tumbuhan merupakan karya seni yang banyak terdapat di kerajaan dan keraton Jawa. Peradaban dan karya seni Jawa selalu berkaitan dengan alam yang tentu saja menjadikan hewan dan tumbuhan sebagai objek imajinasi dan kreativitas seniman Jawa.

Ornamen seperti ini jarang dijumpai di masjid-masjid, hal ini dianggap tidak sesuai dengan ajaran Islam yang melarang manusia membuat bentuk-bentuk yang menyerupai makhluk hidup. Akan tetapi, oleh Syaikh Mutamakkin hal ini disiasati dengan sangat baik melalui penggambaran hewan yang tidak utuh, terpotong, atau tertutupi sesuatu. Cara ini digunakan untuk mengakomodir seni budaya Jawa namun tetap mengandung 
ajaran Islam sehingga tradisi dan budaya tidak dipertentangkan.

Ornamen Burung Bangau yang mematuk bulan sabit digambarkan sedang terbang menuju angkasa namun kakinya tidak terlihat tertutup ornamen lain. Hal yang sama diperlihatkan dua kepala naga tanpa kaki di mana badannya terpotong oleh tiang mimbar. Simbolisasi gajah juga tertutup dengan ornamen lain di bagian perut dan telinga, serta bangau yang tidak kelihatan kakinya. Tingginya keilmuan Syaikh Mutamakkin sangat jelas terlihat dalam karya seni ini, seni budaya Jawa yang berbasis pada alam berpadu dengan ajaran Islam dalam mengajak kepada kebaikan.

Sebuah karya seni yang estetis, indah, penuh makna, dan sarat ajaran agama Islam yang disajikan dalam bentuk karya seni. Pendekatan kultural seperti ini dilakukan oleh Walisongo sehingga dalam kurun waktu yang relatif singkat, Islam diterima oleh sebagian besar masyarakat nusantara. Walisongo hadir bukan untuk menghancurkan peradaban dan kebudayaan jawa, namun meluruskan akidah dan menuntun kepada akhlakul karimah. Tradisi dan kebudayaan yang merupakan kearifan lokal diakomodir sedemikian rupa sehingga melahirkan kebudayaan baru akulturasi Islam dan jawa.

Beberapa ornamen yang terdapat dalam Masjid Jami Kajen (Rizal 2017) yang dibangun oleh Syekh Mutamakkin dan Haji Syamsudin dengan makna filosofisnya dapat dijelaskan sebagai berikut'

\section{Kuntul Nucuk Bulan}

Kuntul dalam bahasa Indonesia berarti Bangau. Bangau dengan ujung paruhnya yang menempel pada bulan sabit menggambarkan seolah-olah bangau sedang berusaha nucuk (mematuk) bulan. Bulan sabit dapat diartikan cahaya yang menerangi kegelapan, Islam merupakan penerang bagi zaman kegelapan yang penuh dengan kesesatan. Maka

${ }^{9}$ Mohammad Zuli Rizal, Infografis Masjid Kajen, (Pati: Perpustakaan Mutamakkin Press, 2017) menggapai bulan berarti menuju ke arah cahaya Islam yang mengajarkan kebaikan dan kedamaian. Bulan sabit yang berada di angkasa diartikan pula cita-cita yang tinggi, sehingga makna bulan di sini adalah setiap manusia harus mempunyai cita-cita yang tinggi.

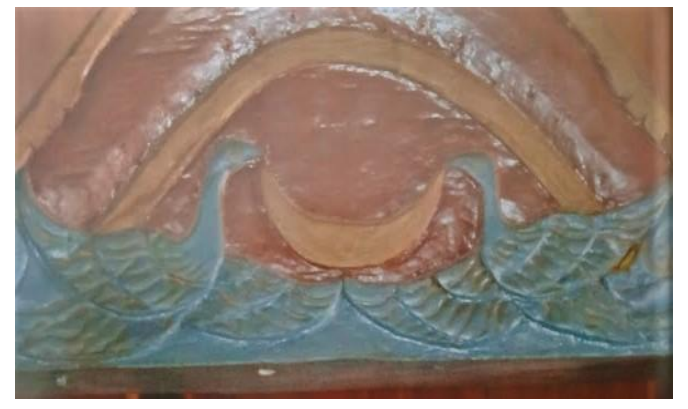

Gambar 2 Kuntul Nucuk Bulan

Kuntul (Bangau) dengan sayapnya yang mengepak menunjukkan perjuangan bangau yang terbang menuju bulan (ajaran Islam, citacita mulia). Ajaran Islam yang penuh Rahmat tidak datang begitu saja, namun dibutuhkan perjuangan belajar tentang ajaran agama Islam, memahaminya, kemudian menjalankan dan mengamalkan ajaran Islam di segala bidang kehidupan. Proses ini tentu tidak mudah karena berbagai godaan nafsu dan halangan akan selalu ada. Bangau dapat pula dimaknai sebagai binatang yang mampu hidup di berbagai lingkungan seperti pantai, sawah, maupun raw-rawa. Ia diibaratkan binatang yang menerima apa yang ada di sekitarnya, di pantai bisa makan ikan, di sawah makan katak atau tumbuhan.

Begitu pula dalam meraih cita-cita mulia, seseorang tidak akan mampu mewujudkan cita-cita jika tidak berusaha sekuat tenaga, baik jiwa maupun raga. Kekuatan manusia adalah akal dan hatinya, ibarat bangau yang mengepakkan sayap supaya dapat terbang menuju bulan, manusia juga diharuskan menggunakan akal dan hatinya dalam menjalani tugasnya di dunia sebagai khalifah, yakni ibadatullah dan imarotul ardl agar mampu meraih saadatuddarain (kebahagiaan di dunia dan akhirat). 
Jadi dapat disimpulkan bahwa ornamen Kuntul Nyucuk Bulan mengajarkan kepada manusia untuk selalu berusaha sekuat tenaga mengamalkan ajaran agama Islam supaya tercapai kedamaian hidup dan kebahagiaan dunia akhirat. Juga mengingatkan kepada manusia untuk memiliki cita-cita dan tujuan dalam kehidupan ini. Tanpa cita-cita dan tujuan maka hidup manusia hanya akan berada dalam kesesatan dan kebahagiaan yang semu.

2. Naga Aji Saka

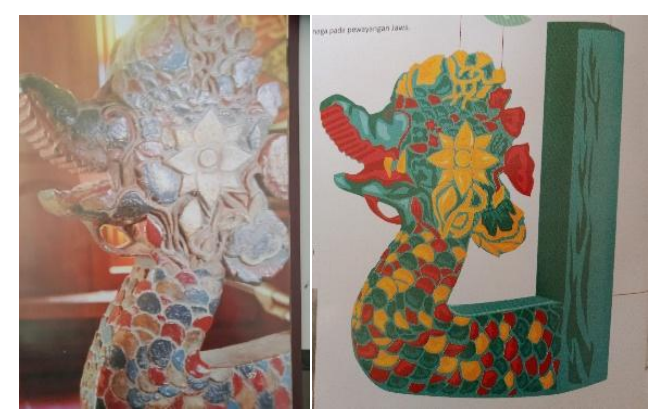

Gambar 3

Kepala Naga Aji Saka dan visualisasi dalam Rizal, 2017 (kanan)

Naga merupakan hewan jenis ular yang banyak ditemui dalam mitologi jawa. Ornamen dua ekor ular naga ini terlihat sangat mencolok di mimbar masjid karena berada di bagian depan mimbar dengan kepala tegak seakanakan naga ini yang mengangkat mimbar masjid. Bagian tubuh dan kepala nampak motif stilisasi atau penyederhanaan dari tumbuhan. Tubuh naga bagian belakang terpotong oleh tiang mimbar sehingga ukiran naga ini tidak utuh, sesuai pendapat banyak ulama fiqh yang tidak membolehkan ukiran hewan dalam keadaan utuh.

Bizawie mengatakan bahwa dua naga tersebut adalah kepala naganya legenda tanah Jawa yang membawa Islam masuk ke nusantara, yakni Aji saka. Sebuah penghormatan terhadap jasa Aji Saka karena perjuangannya membawa dan menyebarkan ajaran Islam di tanah jawa. Aji Saka terkenal sebagai peletak penanggalan Saka dalam kebudayaan jawa.

Ular melambangkan keuletan dan kegesitan sekaligus hewan yang mengajari menahan diri dari nafsu. Ular hanya makan ketika sangat lapar, sejalan dengan ajaran Islam untuk berpuasa, menahan diri dari hawa nafsu. Manfaat berpuasa sangat baik bagi kesehatan tubuh dan akal karena metabolisme tubuh terjaga dan akhirnya dapat berpikir dengan jernih.

\section{Gajah, Trisula, dan Taman}

Ornamen dalam Masjid Jami kajen selanjutnya ialah Gajah yang membawa senjata Trisula di sebuah taman bunga dengan beberapa hewan seperti burung dan ikan. Ornamen ini melambangkan manusia dengan kekuatan dan senjatanya harus mampu menaklukkan nafsu keduniawian berupa berbagai keindahan dan kenikmatan yang ada di dunia. Gajah berarti kekuatan dan dorongan besar dalam diri manusia sebagaimana nafsu, sementara Trisula merupakan pusaka tradisional yang digunakan untuk memerangi hawa nafsu tersebut. Trisula dapat pula berarti tiga ajaran Islam yaitu Iman, Islam, dan Ihsan yang menjadi pusaka utama agar manusia selamat di dunia dan akhirat.

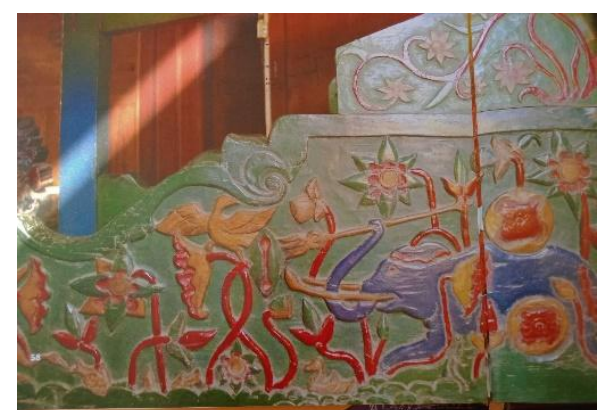

Gambar 4

Gajah, Trisula, Burung, Ikan dan Tumbuh-tumbuhan

Burung Elang, Bangau, ikan, bunga, dan beragam keindahan dunia lainnya menjadi lambang akan fenomena kehidupan dunia yang penuh dengan kenikmatan semu. Bagi manusia yang tergoda dengan kehidupan dunia sehingga melupakan tugas sebagai khalifah untuk beribadah dan menjaga bumi, maka ia tidak akan mendapatkan kebahagiaan di akhirat. Dorongan hawa nafsu yang besar akan selalu mengajak manusia untuk menikmati dunia dan melupakan akhirat. Namun dengan bekal senjata pusaka -Iman, Islam, dan Ihsan- kehidupan dunia akan mampu ditaklukkan dengan menjadikannya 
lahan menanam kebaikan supaya dapat memanen kebahagiaan sejati.

Sebuah gambaran kehidupan dunia yang fana dengan pelajaran berharga untuk tidak terlena sangat jelas terlihat dari ornamen ini. Manusia dibekali kekuatan untuk berusaha memerangi hawa nafsu dengan tidak boleh meninggalkan kepasarahan melalui doa kepada Alllah SWT. Manusia dituntut untuk berusaha dengan segenap kekuatan yang dimiliki, jasmani maupun rohani, kemudian baru menyerahkan semua kepada Allah melalui kegiatan berdoa. Usaha dan doa akan membawa manusia menuju kemenangan melawan nafsu hewani yang mengajak kepada kesenangan dan kebahagiaan semu.

\section{Papan Bersurat}

Tepat di sebelah mimbar terdapat papan yang berisi ukiran kaligrafi dan pesan yang disampaikan dalam bahasa Arab dan Jawa. Letaknya tepat di depan tempat sholat imam sehingga bisa dilihat dan dibaca oleh jamaah yang hadir di masjid. Papan ini memiliki beberapa ornamen yang antara lain pahatan huruf Arab Pegon di papan bertuliskan "sing pendetku ngusap ing mbun", artinya yang keturunan (mengikuti)ku mengusap mbun atau sebagian dari kepala (wudlu). Pesan ini mengajak siapa saja keturunan Syaikh Mutamakkin, baik keturunan secara biologis maupun keturunan secara keilmuan (santri dan anak cucunya) wajib menjaga wudlu. Menjaga wudlu berarti pula menegakkan sholat karena sholat adalah tiang agama. Jika wudlunya tidak dijaga, shalatnya tidak ditegakkan berakibat pada robohnya ajaran agama dalam kehidupan masyarakat karena tiangnya rapuh.
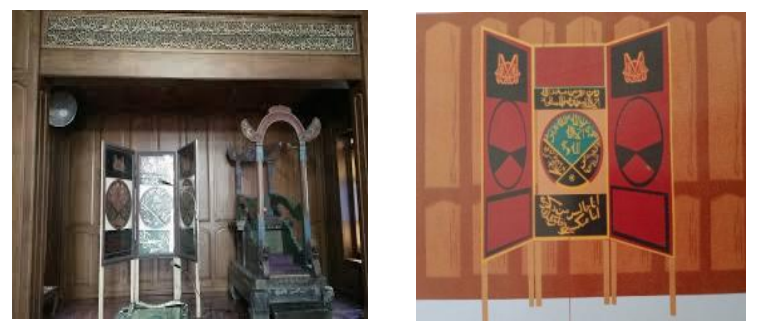

Gambar 5

Papan bersurat di samping mimbar, visualisasi Rizal, 2017 (kanan)
Menarik sekali pesan yang disampaikan dalam papan ini, khas budaya lokal jawa di mana pelajaran bagi manusia disampaikan dengan estetika dan filosofis. Keturunan di sini ialah anak cucu Syaikh Mutamakkin (keturunan biologis) dan juga keturunan ajaran Islam (santri beserta anak cucunya) sehingga siapa saja yang berguru kepada anak cucunya Syaikh Mutamakkin dapat dikatakan sebagai pendet-nya sehingga diperintahkan untuk menjaga shalat. Tidak ada perlakuan secara khusus terhadap nasab, namun meliputi semua masyarakat.

Penyampaian dalam tulisan Arab menggunakan bahasa lokal Jawa -biasa disebut Arab Pegon- menjadi bukti kearifan lokal dan strategi berdakwah Syaikh Mutamakkin dengan pendekatan kultural. Beliau menyampaikan ajaran Islam bukan dengan paksaan atau kekerasan melainkan melalui pendekatan budaya dengan melakukan akulturasi budaya Islam dan Jawa dengan tetap berpegang teguh pada ajaran agama Islam.

Selain pesan dalam bahasa Jawa, terdapat Hadits dalam bahasa Arab yakni perintah untuk memakmurkan masjid bagi orang yang beriman dan beramal shaleh. Keutamaan mereka yang memakmurkan masjid adalah Allah akan bersemayam dalam hati. Pesan itu terpahat dalam papan di bagian paling bawah, Ana jalisun man dzakarani munkasirun fi qulubi abdi, merupakan Hadis Qudsi yang artinya Aku (Allah) bersama orang-orang yang selalu mengingat-Nya (zikir) dan bersemayam dalam hati orang-orang yang bertaqwa. ${ }^{10}$ (Rizal 2017).

Dalam papan bersurat ini terdapat sebuah gambar rakit yang di atasnya terdapat pohon kelapa. Rakit menjadi perumpamaan kehidupan manusia yang mengarungi sungai dengan berbagai halangan dan rintangan. Dibutuhkan kekuatan dan konsentrasi agar rakit mencapai tujuan dengan selamat

${ }^{10}$ Mohammad Zuli Rizal, Infografis Masjid Kajen, (Pati: Perpustakaan Mutamakkin Press, 2017) 
dan lancar. Menaiki rakit berarti menjaga keseimbangan, mengikuti arus, serta menjaga prinsip dengan baik, ibaratnya menjaga ajaran Islam dalam setiap aktivitas.

Sementara pohon kelapa di atas rakit menjadi simbol kesempurnaan manusia, yakni manusia yang mampu memberikan manfaat untuk semuanya. Sesuai Hadits Nabi bahwa manusia terbaik adalah yang paling banyak memberikan manfaat untuk manusia lainnya. Pohon kelapa adalah pohon yang semua bagiannya dapat dimanfaatkan untuk segala kebutuhan manusia. Mulai dari daun hingga akarnya kelapa bermanfaat bagi manusia. Selain itu kelapa merupakan pohon yang bisa ditemui di segala lingkungan, pegunungan, dataran, hingga tepi pantai. Hal ini mengajarkan manusia untuk dapat beradaptasi dalam segala kehidupan tanpa mengeluh dan pesimis.

Yang utama tentu saja pohon kelapa adalah pohon yang tidak mengenal musim panen. Kelapa dapat berbuah kapan saja dan di mana saja sehingga manusia selalu bisa mengambil buah kelapa tanpa mengenal musim. Pohon kelapa tidak berhenti berbuah, maka manusia juga tidak boleh berhenti menebarkan manfaat dan kebaikan kepada manusia lainnya dan juga alam seisinya. Buah kelapa adalah hasil dari segala kebaikan yang disemai sehingga manfaatnya jauh lebih banyak daripada usaha yang dilakukan.

5. Kaligrafi

Kaligrafi yang sederhana namun menunjukkan estetika sekaligus pelajaran berharga terdapat di langit-langit masjid. Kaligrafi tersebut brebentuk segi empat dengan lingkaran di dalamnya di mana lingkaran tersebut di bagian tepinya merupakan asmaul husna dalam butiran bulatan kecil seperti tasbih. Lingkaran tersebut dipagari dengan bacaan zikir yang paling utama yaitu Laa Ilaha Illallah, yakni bersyahadat/bersaksi bahwa tiada Tuhan selain Allah. Syahadat adalah gerbang pertama dan utama dalam Islam, seorang tidak diakui sebagai muslim jika tidak mengucapkan kalimat syahadat, meyakini, dan mengamalkannya dalam kehidupan.

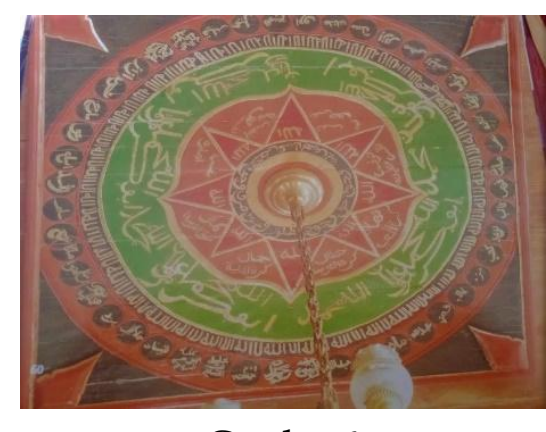

Gambar 6

\section{Kaligrafi di langit-langit Masjid}

Kaligrafi ini terletak di bagian atas (langitlangit) yang melambangkan bahwa Allah SWT berada pada titik tertinggi kehidupan. Maka manusia tidak boleh sombong dengan segala yang dimilikinya karena Yang Maha Segalanya adalah Allah SWT. Isi dari kaligrafi adalah bacaan zikir yang mampu membawa manusia menuju ketentraman batin karena ketika berzikir manusia sangat dekat dengan Tuhannya. Dalam kondisi apapun manusia diperintahkan untuk selalu mengingat Allah, jika semua diserahkan kepada Allah tentu hidup terasa nyaman.

Lingkaran-lingkaran kecil yang memutar merupakan simbol butiran tasbih. Dalam tradisi Islam Jawa, tasbih digunakan sebagai alat bantu dalam berzikir terutama dalam menghitung bacaan zikir. Tidak mengherankan apabila ulama di nusantara digambarkan sebagai sosok yang selalu membawa tasbih. Tasbih adalah simbol zikir, membawa tasbih berarti para ulama senantiasa berzikir kepada Allah dalam berbagai keadaan.

\section{Kontribusi Ornamen Masjid Jami Kajen dalam Penguatan Karakter MI}

Mata pelajaran Pendidikan Agama Islam (PAI) sasaran utamanya adalah untuk melatih dan membentuk hati nurani yang bersih. Jika hati nurani baik maka semua perilakunya akan menjadi baik. ${ }^{11}$. Pada jenjang pendidikan

${ }^{11}$ Keputusan Menteri Agama RI No. 183 Tahun 2019 tentang Kurikulum PAI dan Bahasa Arab pada Madrasah 
dasar, MI merupakan lembaga pendidikan yang menarik karena menggabungkan keunggulan Sekolah Dasar yang menonjol pada pengetahuan umum dengan pesantren yang menitikberatkan pada pengetahuan agama. Dengan karakteristik MI yang unik dan menarik, tertanam optimisme tinggi untuk dapat meraih keberhasilan dalam upaya mewujudkan cita-cita dan tujuan pendidikan.

Masa belajar di MI merupakan masa pembentukan karakter anak, ibarat sebuah bangunan maka pondasinya dibangun ketika pendidikan usia dini dan pendidikan dasar. Pendekatan tematik yang mengintegrasikan beberapa mata pelajaran dalam satu tema sangat tepat untuk dijadikan materi pelajaran sesuai perkembangan dan pertumbuhan peserta didik. Setiap peserta didik menurut Kadir $^{12}$ mendapat informasi baru -pengetahuan atau pengalaman- akan selalu terhubung dengan pengetahuan dan pengalaman yang sudah dimiliki baik secara asimilatif maupun akomodatif. Dalam pembelajaran peserta didik harus diberi kesempatan untuk membangun pengetahuan secara aktif dalam kegiatan yang dilakukan peserta didik sehingga dapat menerima pengetahuan dari sumber kurikulum yang telah disusun. ${ }^{13}$

Pembelajaran tematik dan pembelajaran aktif merupakan salah satu upaya agar anak didik MI mampu mencapai level berpikir tingkat tinggi mengikuti keterampilan global abad 21 yang dikenal dengan sebutan HOTS (High Order Thinking Skill) dengan keterampilan 4C yaitu Critical Thinking, Creative, Communicative, dan Collaborative. Di era disruptif sekarang ini, menumbuhkan dan membekali anak didik MI dengan keterampilan tersebut adalah sebuah keniscayaan. ${ }^{14}$ Selain keterampilan

${ }^{12}$ Abd. Kadir dan Hanun Asrohah, Pembelajaran Tematik, (Jakarta: Rajawali Press, 2014)

${ }^{13}$ T. Anderson \& Armbruster, B., Reader and Text Studying Strategies, (W. O. White, Ed.), (New York: Academic Press, 1982)

${ }^{14}$ Andi Prastowo, "Permainan Tradisional Jawa Sebagai Strategi Pembelajaran Berbasis Kearifan Lokal Untuk Menumbuhkan Keterampilan Global Di MI/ berpikir tingkat tinggi, amanat kurikulum 2013 menghendaki pembelajaran yang mampu meningkatkan literasi sekolah/madrasah.

Orientasi lain dari pembelajaran dalam kurikulum 2013 ialah penguatan pendidikan karakter. Dari 18 nilai karakter yang terangkum dalam kurikulum 2013 kemudian dirangkum menjadi lima penguatan pendidikan karakter yaitu karakter nasionalis, religius, mandiri, integritas, dan gotong royong. Untuk mencapai karakter yang diharapkan setidaknya harus memperhatikan tiga hal yang berhubungan dengan karakter menurut Lickona ${ }^{15}$, yakni pengetahuan, perasaan, dan perilaku moral. Kaitannya dengan pemguatan karakter maka anak didik harus diajarkan tentang pengetahuan, perasaan, dan perilaku yang sesuai dengan norma masyarakat (kearifan lokal).

Masjid Jami Kajen sejak awal berdiri hingga sekarang berfungsi tidak hanya sebagai tempat ibadah shalat, tetapi juga sebagai pusat peradaban yang berkaitan dengan keagamaan, sosial dan budaya masyarakat Islam. ${ }^{16}$ Peran masjid ini antara lain sebagai pusat pendidikan Islam, tempat menuntut ilmu (kajian kitab kuning), melestarikan tradisi (megengan, selametan, suronan), sekaligus kegiatan sosial kemasyarakatan seperti santunan anak yatim dan kaum miskin. Dapat dikatakan bahwa masjid ini berpotensi menjadi sumber sekaligus media pembelajaran untuk penguatan karakter mandiri anak didik berbasis kearifan lokal.

Salah satu bagian penting dari Masjid Jami Kajen yang dapat memberikan kontribusi bagi penguatan karakter anak didik di MI ialah ornamen masjidnya. Ornamen yang menghiasi bangunan Masjid Jami Kajen bukan hanya berfungsi sebagai hiasan semata namun sarat dengan pelajaran dan makna filosofis bagi

SD", JMIE: Journal of Madrasah Ibtidaiyah Education, 2 (1), (2018) h. 1-28

${ }^{15}$ Thomas Lickona, Character Matter (Persoalan Karakter), (Jakarta: Bumi Aksara, 2013)

16 Novita Siswayanti, "Mengenal Masjid Nahdliyin dalam Peranan Masjid Jami Kajen", Bimas Islam, VII, No. II (2018), h. 277-300 
kehidupan. Syaikh Mutamakkin menjadikan ornamen masjid sebagai hiasan sekaligus media dakwah kepada santri dan masyarakat sekitar.

Hasil analisis terhadap ornamen Masjid Jami Kajen dan kontribusinya dalam penguatan karakter anak didik MI sebagai upaya membentuk keterampilan $4 \mathrm{C}$ sesuai perkembangan zaman dapat dilihat dari 5 ornamennya, yaitu ornamen Kuntul Nucuk Bulan, Naga Aji Saka, Gajah-Trisula-Taman, Papan Bersurat, dan ornamen Kaligrafi Langit Masjid. Kelima ornamen tersebut berkontribusi sebagai sumber belajar sekaligus media pembelajaran untuk menguatkan karakter anak didik MI.

Pertama, ornamen Kuntul Nucuk Bulan yang artinya Burung Bangau Mematuk Bulan, ornamen ini melambangkan cita-cita yang tinggi hanya dapat tercapai melalui kerja keras dan usaha yang tiada kenal lelah. Bulan adalah cita-cita tinggi, sementara Bangau yang terbang ke angkasa mengepakkan sayapnya merupakan representasi dari etos kerja (kerja keras), tangguh tahan banting, dan daya juang. Prinsip ini memicu kemampuan anak dalam melakukan sesuatu sehingga tidak lagi bergantung pada orang lain namun dapat menjadi individu yang dapat berdiri sendiri. ${ }^{17}$

Untuk mencapai bulan tidak dapat dikerjakan sekejap saja seperti membalikkan telapak tangan, namun ada proses yang harus dijalani mulai dari bawah, mengepakkan sayap, terbang tinggi, hingga akhirnya mencapai bulan. Ornamen ini dapat dilihat pada mimbar atas bagian belakang, guru dapat menjadikannya sebagai sumber belajar tentang kemandirian, integritas, dan perjuangan. Belajar dari ornamen ini secara langsung juga akan memotivasi anak dalam membetuk karakter diri sekaligus belajar materi lain seperti seni budaya dan Akidah Akhlak.

Kedua, ornamen Naga Aji Saka, berupa dua kepala naga yang menyokong

${ }^{17}$ Marion Dowling, Young Children's Personal, Social and Emotional Development, (Vol. 2), (London: Paul Chapman Publishing, 2005) mimbar dari bawah. Ular melambangkan keuletan, kelincahan, sekaligus kemampuan bertahan diri yang kuat menghadapi cobaan. Kemandirian sangat berhubungan dengan pribadi yang kreatif dan mampu berdiri sendiri, pelajaran yang dapat ditangkap dari ular ialah ia melakukan semua sendiri dan percaya diri. Hurlock ${ }^{18}$ menegaskan bahwa semakin banyak anak melakukan sendiri, semakin besar rasa percaya atas dirinya. Diri yang mandiri harus dibarengi religiusitas yang baik sebagai pondasi karakter anak.

Ular merupakan hewan yang tahan lapar dan tidak makan sebelum benar-benar lapar. Hal ini mengajari anak untuk memperbanyak puasa dan makan seadanya tidak berlebihan. Ornamen ini dapat dijadikan media pembelajaran dalam mata pelajaran Fiqh untuk mengajari anak berpuasa dan tirakat, melakukan semuanya sendiri, dan berani mencoba sesuatu untuk lebih maju. Karakter integritas dan mandiri dapat diajarkan dari ornamen ini sehingga pembelajaran tidak monoton.

Ketiga, ornamen Gajah-Trisula-Taman, ornamen ini menggambarkan bagaimana gajah membawa trisula diibaratkan manusia dengan dorongan hawa nafsu yang besar dihadapkan pada taman yang indah berupa bunga-bunga, burung, ikan, dan keindahan duniawi lain. Gajah adalah gambaran nafsu yang besar, dan taman ialah kehidupan dunia yang penuh keindahan dan kebahagiaan semu.

Untuk bisa mengatasi godaan tersebut, terdapat trisula, senjata tradisional dengan tiga mata tombak yang dapat diartikan sebagai ajaran tentang Iman, Islam, dan Ihsan. Hawa nafsu harus terus ditekan dengan memperbanyak ibadah individual maupun ibadah sosial. Anak dapat diajari menggunakan trisula dalam dirinya melalui pembelajran Quran Hadits dan Akidah Akhlak secara kontekstual sesuai kearifan lokal. Perkembangan kemandirian anak selama

${ }^{18}$ Elizabeth B. Hurlock, Perkembangan Anak, (M. Tjandrasa, Trans.), (Jakarta: Erlangga, 2008) 
tahap awal (pendidikan dasar) memberi keberanian untuk menjadi pribadi yang mandiri yang dapat membuat pilihan dan memimpin masa depannya sendiri. ${ }^{19}$ Selain mandiri, gotong royong dan nasionalisme (cinta tanah kelahiran) dapat diajarkan dengan menggunakan ornamen ini sebagai media pembelajaran dalam mata pelajaran Akidah Akhlak, Fiqh, atau SKI.

Keempat, ornamen Papan Bersurat, merupakan ornamen tiga buah papan persegi panjang yang berdiri tegak berisi ajaran Syaikh Mutamakkin serta Hadits. Pesan Syaikh Mutamakkin ialah sapa seng pendetku ngusap ing mbun, siapa yang keturunanku (anak maupun santri) harus berwudlu dan menegakkan shalat sebagai tiang agama. Shalat mengajarkan anak untuk mandiri yang menurut Covey ${ }^{20}$ memiliki ciri-ciri berupa mampu berpikir sendiri, melakukan sendiri, kreatif mengekspresikan gagasan, dan bertanggung jawwab terhadap kewajibannya.

Pada pesan lain tertulis hadis tentang keutamaan memakmurkan masjid dan orang yang selalu berzikir kepada Allah. Zikir kepada Allah melatih konsentrasi dan ketenangan batin, ini sangat penting dalam menumbuhkan kemandirian anak. Anak yang kesulitan berkonsentrasi dan sering gelisah akan sulit menjadi pribadi yang mandiri dan sering bergantung pada orang lain. Maka pelajaran kalimat toyyibah bisa diamalkan sejak dini dan dibiasakan supaya anak merasa dekat dengan Tuhan sehingga semakin tenang. Karakter religiusitas (perbanyak zikir) dan gotong royong (memakmurkan masjid) menjadi substansi materi yang dapat diajarkan kepada anak didik MI.

Ornamen papan bersurat juga menampilkan sebuah pahatan rakit dengan pohon kelapa di atasnya. Rakit ibarat

${ }^{19}$ John W. Santrock, Life-Span Development, Perkembangan Masa Hidup, (Jakarta: Erlangga, 2002)

${ }^{20}$ Stephen R. Covey, The Seven Habits of Highly Effective People, (Budijanto, Trans.), (Jakarta: Binarupa Aksara, 1997) kehidupan harus dijalani dengan kerja keras menjaga keseimbangan hingga akhirnya mampu memberikan manfaat yang banyak seperti pohon kelapa yang semua bagiannya dapat dimanfaatkan. Manusia terbaik adalah yang paling banyak memberi manfaat, hal ini termaktub dalam hadis yang bisa dikaitkan dengan kondisi masyarakat masa kini dalam melatih keterampilan kolaboratif anak. Ornamen ini memberikan kontribusi dalam pembelajaran al-Qur'an Hadis, Akidah Akhlak, dan SKI.

Kelima, ornamen Kaligrafi Langit Masjid, berisi kalimat syahadat $\mathrm{La}$ ilaha illalah yakni kesaksian bahwa tiada Tuhan selain Allah. Kemudian lingkaran kecil mengelilingi sebuah lingkaran yang melambangkan butiran tasbih. Tasbih adalah simbol zikir dan kedekatan dengan Allah SWT. Jika anak merasa dekat dengan Tuhannya ia akan tumbuh menjadi pribadi yang percaya diri, tenang, dan berani karena yakin Allah bersamanya. Di sisi lain juga akan menjadi pengingat anak ketika mereka akan melakukan perbuatan tercela, karena diawasi Allah akan mengurungkan niat jeleknya.

Kaligrafi kalimat tahlil yang berada di langit-langit masjid menempati tempat tertinggi melambangkan bahwa hanya Allahlah yang paling tinggi, berada di atas segala-galanya dan menguasai alam semesta. Menyadari bahwa Allah yang paling tinggi dapat memberikan pelajaran kepada anak untuk tidak sombong dan tinggi hati. Sifat sombong hanya akan merugikan diri sendiri namun sikap rendah hati akan memotivasi diri untuk mandiri dan berinteraksi dengan orang lain. Pelajaran tentang akhlak karimah dan kalimat toyyibah sangat membantu anak menguatkan karakter mandiri dalam diri anak.

Berdasarkan pemaparan di atas, dapat ditarik kesimpulan bahwa ornamen yang berada di bangunan Masjid Jami Kajen berupa pahatan Kuntul Nucuk Bulan, Naga Aji Saka, Gajah-Trisula-Taman, Papan Bersurat, dan Kaligrafi Langit Masjid mengandung 
pelajaran hidup tentang sosok manusia yang berkarakter, bertaqwa dan beramal shaleh. Landasan penguatan karakter tersebut bukan hanya berasal dari ajaran al-Qur'an dan Hadis (ajaran pokok Islam) namun juga berasal dari kearifan lokal yang dimiliki masyarakat Kajen yakni Masjid Jami kajen dengan segala norma yang berkembang di dalamnya.

Makna kandungan dalam ornamen tersebut dapat dijadikan sumber belajar sekaligus media pembelajaran dalam menguatkan karakter anak didik MI melalui pembelajaran PAI MI berbasis kearifan lokal Masjid Jami Kajen. Memanfaatkan budaya lokal dalam ornamen Masjid Jami Kajen untuk menguatkan karakter anak didik MI melalui pembelajaran dapat dilakukan dengan pendekatan kontektual dan pembelajaran aktif. Anak didik tidak hanya belajar materi tetapi juga diajak mengunjungi masjid dan belajar langsung dari masjid bersejarah.

\section{Kesimpulan}

Berdasarkan penjelasan di atas, dapat ditarik kesimpulan: pertama, ornamen yang terdapat dalam Masjid Jami Kajen memiliki kandungan makna filosofis yang dalam berisi ajaran Islam dan kearifan lokal yang disampaikan oleh Syaikh Mutamakkin melalui karya seni. Ornamen dengan makna simbolik yang terdapat dalam Masjid Jami Kajen yaitu pahatan Kuntul Nucuk Bulan, Naga Aji Saka, Gajah-Trisula-Taman, Papan Bersurat, dan Kaligrafi Langit Masjid. Ajaran yang disampaikan berasal dari ajaran Islam yang bersumber dari Al-Qur'an dan Hadis serta ajaran dari tradisi dan kebudayaan Jawa. Kedua, ornamen dengan makna kandungan ajaran Islam dan budaya lokal dalam Masjid Jami Kajen memberikan kontribusi besar bagi penguatan karakter anak didik MI melalui pembelajaran yang berbasis pada kearifan lokal dengan menjadikan Masjid Jami Kajen sebagai sumber belajar maupun media pembelajaran. Anak didik dapat diajak belajar di masjid atau menjadikan ornamen-ornamen tersebut sebagai materi ajar tentang Aqidah Akhlak, Fiqh, AlQur'an Hadis, maupun SKI. Pembelajaran aktif dan pembelajaran kontektual untuk menguatkan karakter anak didik MI dapat dilakukan dengan menjadikan Masjid Jami Kajen beserta ornamen-ornamennya sebagai basis pembelajaran PAI MI.

\section{Daftar Pustaka}

Anderson T. \& Armbruster, B. Reader and Text Studying Strategies. (W. O. White, Ed.). New York: Academic Press, 1982

Bizawie, Zainul Milal. Syaikh Mutamakkin Perlawanan Kultural Agama Rakyat. Tangerang: Compas Pustaka, 2014

Covey, Stephen R. The Seven Habits of Highly Effective People. (Budijanto, Trans.). Jakarta: Binarupa Aksara, 1997

Dowling, Marion. Young Children's Personal, Social and Emotional Development, (Vol. 2). London: Paul Chapman Publishing, 2005

Fathurrahman. "Masjid Sebagai Pusat Pendidikan Islam Masa Klasik". Jurnal Studi Pemikiran Pendidikan Islam Kreatif. Vol. XII. No. 1 (2015)

Hidayat, Arif. "Masjid dalam Menyikapi Peradaban Baru". Ibda': Jurnal Kebudayaan Islam. Vol. 12 (1), (2014)

Hurlock, Elizabeth B. Perkembangan Anak. (M. Tjandrasa, Trans.). Jakarta: Erlangga, 2008

Ilhaq, Muhsin. "Bentuk dan Penempatan Ornamen pada Mesjid Agung Palembang". Jurnal Ekspresi Seni. 18 (2), (2016)

Kadir, Abd. dan Hanun Asrohah. Pembelajaran Tematik. Jakarta: Rajawali Press, 2014

Keputusan Menteri Agama RI No. 183 Tahun 2019 tentang Kurikulum PAI dan Bahasa Arab pada Madrasah

Kurniawan, Syamsul. "Masjid dalam Lintasan Sejarah Umat Islam". Jurnal Katulistiwa 
- Journal of Islamic Studies. Vol. 4 No. 2 (2014)

Lickona, Thomas. Character Matter (Persoalan Karakter). Jakarta: Bumi Aksara, 2013

Mufid, Ahmad Syafii. Tangklukan, Abangan, dan Tarekat: Kebangkitan Agama di Jawa. Jakarta: Yayasan Obor Indonesia, 2006

Prastowo, Andi. "Permainan Tradisional Jawa Sebagai Strategi Pembelajaran Berbasis Kearifan Lokal Untuk Menumbuhkan Keterampilan Global Di MI/SD". JMIE: Journal of Madrasah Ibtidaiyah Education. 2 (1), (2018)

Rizal, Mohammad Zuli. Infografis Masjid Kajen. Pati: Perpustakaan Mutamakkin Press, 2017

Santrock, John W. Life-Span Development, Perkembangan Masa Hidup. Jakarta: Erlangga, 2002

Shihab, M. Quraish. Membaca Sirah Nabi Muhammad SAW. Jakarta: Lentera Hati, 2011

Siswayanti, Novita. "Mengenal Masjid Nahdliyin dalam Peranan Masjid Jami Kajen". Bimas Islam. VII No. II (2018)

Supriyadi, Bambang. "Kajian Ornamen Pada Mesjid Bersejarah Kawasan Pantura Jawa Tengah". Enclosure. 7 (2), (2008)

Ubaidillah, Ahmad, dan Yuliatin Tajuddin. Suluk Kiai Cebolek (Dalam Konflik Keberagamaan dan Kearifan Lokal). Jakarta: Prenada, 2014 
22 | Elementirl! Vol. 6 No. 1, January-June 2020

This page intentionally left blank 